\title{
Kulturní a etnická proměna středoasijských Korejců
}

\author{
Petr Kokaisl
}

DOI: $10.21104 / C L .2017 .3 .03$

\section{Cultural and ethnic transformation of Koreans in Central Asia}

\begin{abstract}
The principal goal of this article is to demonstrate the cultural and ethnical changes of Koreans living on the territory of Central Asian states of former Soviet Union. The article shows, on the example of Korean minority living in several states how important could be the state interventions for the formation and transformation of cultural and ethnic identity. Koreans living until the 19th century in Korea had, in spite of many regional, dialectic and religious differences, an idea of belonging to the same ethnic group. After the beginning of the outmigration to Russia from northern part of the country due to bad living conditions, there was a relatively rapid (and voluntary) acceptance of Russian culture. After their deportation to Central Asia their culture had begun to change in an even more important way, even though they were aware of their difference and this difference they wanted to maintain in certain areas. Still, they accepted the model of the "Soviet man". Central Asian Koreans as national minority had a problem with identifying
\end{abstract}

with "homeland", as Korea due to diverging political conditions split into two states, officially inhabited by one ethnic group, but de facto with two. By confronting the culture of Central Asian Koreans with the culture in both parts of Korean Peninsula we see clearly that in many respects every one of the three groups is very specific.

Keywords Koreans, Soviet Koreans, ethnicity, collective identity, assimilation, Central Asia, ethnic changes.

Tento článek vznikl za podpory IGA PEF ČZU (č. 20161020).

Contact Doc. Ing. PhDr. Petr Kokaisl, Ph.D., Provozně ekonomická fakulta ČzU v Praze, Kamýcká 129, 16521 Praha, Czech Republic; e-mail: pkokaisl@seznam.cz.

Jak citovat / How to cite Kokaisl, Petr. (2017). Kulturní a etnická proměna středoasijských Korejců. Český lid 104, 339-359. doi:http:// dx.doi.org/10.21104/CL.2017.3.03 
Národnostní menšiny jednoho etnika, žijící na území více států, mohou být vynikající ukázkou vlivu státu na kulturu těchto etnik. Zároveň je možné pozorovat, jak zásahy různých států ovlivnily kulturu původní poměrně jednotné etnické skupiny. $V$ průběhu několika generací dochází k takovým změnám, že už je velmi ošidné hovořit o jednotné etnické skupině, i když tato skupina má stále jedno označení (etnonymum). Tento příspěvek chce ukázat na příkladu Korejců, kteří na přelomu 19. a 20. století odcházeli z ekonomických důvodů na ruský Dálný východ, jak jejich národní kulturu i etnické povědomí proměnil ruský a později sovětský stát a k jakým dalším proměnám v jejich kultuře dochází po vzniku nových států po rozpadu SSSR.

\section{Článek se snaží dát odpověd' na tyto otázky:}

- Co považují sovětští Korejci za typické prvky své kultury, nakolik lze hovořit o jednotné korejské kultuře?

- Jaké jsou hlavní podobnosti a rozdíly mezi kulturou sovětských Korejců a Korejců žijících na Korejském poloostrově (Severokorejců a Jihokorejců)?

- Jaké vlivy působí na vydělování kulturních a etnických odlišností Korejců nejvýrazněji?

Tato práce vychází z prováděného opakovaného střednědobého výzkumu korejské minority v Uzbekistánu, Kyrgyzstánu a Kazachstánu v letech 20132015. Cílem bylo získat vedením polostrukturovaných rozhovorů s korejskými respondenty kvalitativní údaje, které doplní a rozšírí dosavadní publikace o sovětských Korejcích - osobní pohled respondentů je pro výzkum vnímání vlastní kultury a etnicity nepostradatelný.

Nejvíce odborné literatury týkající se kultury sovětských Korejců (Korjǒsaram) píší prrímo členové této skupiny. Od 90. let 20. století začalo vycházet množství memoárové literatury, kde hlavním středobodem byl odsun Korejců z Dálného východu. Je s podivem, že v obou korejských republikách neprobíhá ve větší míře systematická výzkumná činnost mapující korejské menšiny na území Střední Asie. Určitou výjimkou je například E. Yim, který publikuje práce týkající se identity Korejců v Kazachstánu. Větší zájem o výzkum sovětských Korejců je patrný ze strany ruských a ruskojazyčných autorů (G. Kim), popřípadě autorů japonských (S. Oka, který porovnává i další středoasijské menšiny).

Jednoznačně vymezit etnickou skupinu podle dichotomie „my“ a „oni“ (Muszynski 1994) je často nemožné, ale spíše bývá přesnější její zařazení na škále „my“ - „nám podobní“ - „bližší oni“ - „vzdálenější oni“. Pro většinu minoritních etnik je typické vyčleňování vůči majoritě - zde je možné zmínit teorii německého sociologa Georga Simmela (Simmel 1890: 140-141), který ovšem nehovoří o etnických, ale sociálních skupinách. Podle něj jednotlivé skupiny stojí vůči sobě v protikladu. Tento konflikt vytváří hranice mezi jednotlivými skupinami uvnitř jednoho systému, ale zároveň v rámci skupin 
vytváŕí skupinovou identitu jejích členů. Konflikt mezi skupinami není nutně negativní, ale má význam pro celý sociální systém, protože uvnitř skupin vytváŕí soudržnost. Tuto teorii rozvádí Eriksen (2007: 73), když uvádí, že síla identifikace se skupinou závisí na míře vnějšího tlaku (státu, odlišné etnické skupiny).

Skupiny ovšem nevznikají jen kvůli vnějšímu tlaku, ale i proto, že jednotliví členové mají z tohoto uskupení (a vymezování) určitý prospěch. Skupina musí jednotlivým členům nabízet výhody, které povedou ke vzájemné solidaritě a loajalitě; někteří autoři, jako například Tătar (2010), uvádějí i prvek hrdosti na př́slušnost $\mathrm{k}$ dané skupině.

Máme-li aplikovat tyto teorie na národnostní menšinu středoasijských Korejců, je i zde velmi dobře vidět, že jednotlivá středoasijská etnika netvoří jednoznačné skupiny „my“ a „oni“, ale často se překrývají. Zařazování na škálu „my“ a „ostatní“ mívá často hranice kulturní. Může se jednat o hranice mezi naším uspořádaným světem a světem zvenčí, který naše zvyklosti nerespektuje. Například v Kazachstánu nemusí být vždy důležitá etnická hranice - kazašské etnikum vnímá kulturní blízkost místních Korejců (se kterými je bezkonfliktní soužití), a naopak často negativně vnímá kulturní odlišnosti Kazachů, kteří se do země nedávno přistěhovali z Mongolska nebo z Číny. Přes proklamace o jednom kazašském národu dochází mezi místními a přistěhovalými Kazachy ke konfliktům.

\section{Analýza etnické identity v sovětském a středoasijském prostoru}

V sovětském a postsovětském prostoru mají pojmy národ, národnost, etnikum, ethnos, etnická identita mnohdy odlišnou definici ve srovnání se střední (a ještě více západní) Evropou.

Použití pojmu národ (narod/народ) bylo v sovětském prostředí (a doposud je i na velké části postsovětského prostoru) typické pro politické chápání skupin na území státu, bez ohledu na jejich etnický původ. Proto se používal další pojem ethnos (fakticky synonymum pojmu etnikum) pro etnickou skupinu, která mohla pobývat na území různých států, a tak jeden ethnos mohl být součástí více různých národů (obyvatel různých státních útvarů). Podobně jeden národ je tvořen různými etnickými skupinami - ethnosy.

V prvních letech po bolševické revoluci v Rusku se Leninově a Stalinově modelu řešení národnostní otázky blížil evropský „trojjediný“ model či ideál jednoty jazyka, národa (etnicity) a politického útvaru (Šatava 2015: 5). Nejprve docházelo k vytváření správních jednotek na národnostním principu s různou mírou autonomie (od autonomních okresů přes autonomní oblasti až k národním svazovým republikám). Ve většině případů se nejednalo o proces, který by byl iniciovaný „zdola“, jak uvádělo oficiální stanovisko: „V roce 1924 vytvořily všechny středoasijské národy po vzájemné dohodě zcela nové politicko-správní rozdělení Střední Asie, které zohledňovalo ekonomické a politické 
zájmy každého národa. "Středoasijské obyvatelstvo totiž bylo z větší části negramotné a nemělo žádné vyhraněné národnostní ponětí nebo ponětí o jedné sovětské zemi, o socialistické vlasti (Kokaisl - Usmanov 2012: 146).

Olivier Roy (2007: 61) považuje situaci v prvních letech sovětské vlády ve Střední Asii za naprosto unikátní a uvádí, že koloniální moc (označení sovětské vlády jako koloniální je ovšem v mnoha ohledech sporné) poprvé v dějinách stvořila nejen nové státy, ale i nové jazyky a národní dějiny včetně folkloru a literatury.

Za unikátní považoval tuto situaci i sovětský disident Alexandr Solženicyn (1999: 115-120), podle kterého vznik nových autonomních útvarů neměl vést k odstranění centralizovaného státu, ale naopak, za přispění zpevněné stranické diktatury, byl tvrdě realizován fakticky unitární stát. Hesla o sebeurčení národů získávala uvnitř Ruska za spojence všechny menší národy, mimo Rusko pak přitažlivým př́kladem vzbuzovala sympatie národů Východu.

Po vytvoření autonomních jednotek na etnickém základě došlo v SSSR k prudkému obratu a od konce 30. let 20. století se jakýkoli náznak na národnostní specifika začal označovat jako nacionalistická úchylka, za kterou byla popravena celá řada nejvyšších sovětských funkcionářủ stojících v čele autonomních národnostních jednotek. V tomto období začala být velmi důležitá oficiální národnost (nacional'nost'/национальность), která se zapisovala do dokladů. Tato nacionalnost' odpovídala pojmu ethnos (etnikum). Přestože se v současnosti ve střední a západní Evropě pojem národ chápe především jako jednotka kulturní a etnikum bývá často považováno za synonymum národa (Kokaislová 2013), neplatí to zcela. Existuje řada teoretiků, kteří definují národ prostřednictvím státnosti - v tomto případě pak rozlišují národy (disponují vlastním státem) a etnika (bez vlastního státu). Podobné rozlišení se uplatňovalo i ve Střední Asii - pojem byl sice jeden, ale národnost (nacionalinost) odpovídající příslušné svazové republice byla jednoznačně prestižnější než národnost skupin, které žádnou autonomní jednotkou nedisponovaly.

V některých případech bylo možné se pro žádoucí národnost rozhodnout - ve Střední Asii byly preferované národnosti odpovídající příslušným svazovým republikám. Ujguři se tak často kvůli možnosti kariérního postupu zapisovali jako Uzbeci, mnoho uzbeckých Tádžiků bylo naopak zapsaných jako Uzbeci proti jejich vůli. V př́ípadě nespolehlivých národů (Poláci, Němci, Korejci...) možnost vlastního výběru národnosti rovněž neexistovala - o národnosti těchto osob rozhodovali úředníci. Zapisovaná národnost dětí musela odpovídat národnosti jednoho z rodičů, nejčastěji otce. V období do 30. let 20. století tak docházelo ve Střední Asii k rychlému a umělému vytváření nové národní identity, kterou později výrazně překrývala identita supranacionální - sovětská.

Sovětská etnická identita měla prvotně propojenost se sovětskou státní příslušností, sovětskou ideologií a sovětským patriotismem (vytvoření sovětského člověka) a teprve nižší vrstvy etnické identity mohly zahrnovat identitu 
národnostní. Sovětský národ byl označovaný jako osobitý ethnos, protože na rozdíl od ostatních národů (ethnosů) nebyl formovaný specifickými tradicemi, jazykem nebo historickým povědomím (Kim 1972).

Po rozpadu SSSR se středoasijské republiky snažily zaručit vedoucí úlohu ve státě titulárním národnostem. V tomto ohledu současné středoasijské režimy pozoruhodně navazují na sovětské metody. Nové jazykové zákony, přijaté ještě před získáním nezávislosti, učinily z titulárních řečí nikoli předpoklad občanství (jako tomu bylo například v Pobaltí), ale určitého sociálního statutu (Ditrych 2004).

\section{Historické pozadí Migrace Korejců z Koreje}

Příchod Korejců do Střední Asie je spojený především s jejich deportací před 2. světovou válkou z ruského Dálného východu, kam přišli ve dvou hlavních vlnách: jedna spadá do 2. poloviny 19. století, druhá do let 1910-1928.

V první vlně Korejci z území dnešní severní Koreje postupně osidlovali neobydlené území. První informace z tohoto období máme od ruského cestovatele Převalského z roku 1867. Převalskij (1870: 106) popisoval důvody, proč Korejci odešli do Ruska (bída a přelidněnost korejských oblastí, despotismus místních feudálů), a zmiňoval i vznik prvních korejských vesnic na březích řek (Tyzen-che, Janči-che a Sidimi).

V roce 1863 do Ruska odešlo 12 korejských rodin a v roce 1867 už zde žilo 1800 osob. Proti této migraci se korejští představitelé bránili a nelegální přechod hranice do Ruska trestali zastřelením. Naopak ruská vláda Korejce podporovala. Převalskij u přesídlených Korejců (kteří se sami označovali Kauli) oceňoval jejich pracovitost a (na rozdíl od Číñanů) čistotnost. Zmiňoval i to, že někteří Korejci měli více žen - ženy ovšem neměly vlastní jména, ale označovaly se jen příbuzenskými termíny (matka, teta). Přestože od příchodu prvních Korejců do Ruska uběhlo jen několik let, někteří Korejci již přijali pravoslaví a korejská jména vyměnili za ruská (Převalskij 1870: 105-119).

V důsledku neúrody a hladu v severní Koreji se v zimě roku 1869 příchod Korejců do Ruska zintenzivnil. N. A. Nasekin (1904: 1-61) zaznamenal střelbu korejských ozbrojenců do korejských uprchlíků snažících se dostat do Ruska a popisoval množství mrtvých těl na korejském břehu pohraniční řeky. V 70. letech 19. století už bylo na ruském Dálném východě 32 korejských vesnic. Nasekin uváděl, že se Korejci zabývali především rostlinnou výrobou, skot měli jen jako tažný. Protože vůbec nepili mléko, krávy nedojili.

Pro toto prvotní období bylo charakteristické udržování korejských zvyklostí a pouze postupné a spíše vnějškové přejímání ruských kulturních prvků. Začleňování Korejců mělo i ekonomické důvody - ruští občané platili menší daně a mohli legálně získávat půdu. K získání občanství (poddanství) se však vyžadovala loajalita (znalost jazyka, přijetí pravoslaví). Kulturní začlenění 
ovšem nebylo z mnoha důvodů proveditelné okamžitě. Korejci se od Rusů odlišovali ve všech ohledech - stavbou domů, nošením dlouhých vlasů u žen i mužů, stravováním, vyšší solidaritou oproti více individualistickému ruskému přístupu. Korejci se zpočátku bránili sňatkům s Rusy a raději si partnery hledali v Koreji (Chan - Sim 2014: 51-52).

Druhá vlna příchodu Korejců do Ruska spadá do období korejsko-japonské války, kdy Japonci anektovali Koreu (roku 1910). Na území Ruska (podobně jako v Číně nebo USA) vzniklo několik korejských škol a působily skupiny usilující o svržení japonské okupační vlády (Han 2010: 122-123). Situace Korejců v Rusku byla př́íznivá, ale později Korejci s ruským poddanstvím museli bojovat v ruské armádě v 1 . světové válce.

„Většina Korejců na Dálném východě byli pravoslavní křestané, protože tak chtěli ukázat loajalitu ruskému carovi-nechávali se pokřtít, a tak snáze získávali ruské poddanství. Během 1. světové války ovšem museli jako poddaní cara bojovat na frontě s Rakousko-Uherskem. Dědeček bojoval ve válce společně s bratrem." (Vladislav Viktorovič Chan, Terénní výzkum, Taškent 2014)

Příchod Korejců do Ruska pokračoval i po skončení 1. světové války zejména po neúspěšném tzv. Povstání 1. dubna v roce 1919. Až do roku 1927 byla hranice mezi Koreou a Ruskem (SSSR) snadno průchozí a až v roce 1928 sovětská vláda př́íchod korejských migrantů znemožnila (Korejcy 2014: 58).

Korejci, kteří přišli do Ruska v důsledku obsazení Koreje Japonskem, se od předchozích migrantů výrazně odlišovali - šlo hlavně o politické migranty, kteří chtěli z Ruska vést boj za samostatnost Koreje. Součástí tohoto boje byla i korejská angažovanost na poli kulturním a vzdělávacím. Přestože vedle sebe žily dvě skupiny Korejců, nedocházelo mezi nimi k výraznému odlišování na základě doby prožité v Rusku. Rozvrstvení Korejců bylo spíše z hlediska sociálního nebo vzdělanostního (Grigorcevič 1958).

Po skončení 1 . světové války bylo velké množství ruských Korejců nakloněno bolševickým ideálům a Korejci se stávali obhájci sovětského uspořádání. Většinou se jednalo o Korejce (a jejich potomky), kteří přišli na ruské území již v 19. století. K bolševikům měli blízko i Korejci, kteří se angažovali v protijaponském odboji.

Jakmile bolševici převzali moc, začalo vyvlastňování majetku - nejprve u bohatých osob. Když probíhala v Rusku (SSSR) první vlna vyvlastňování a rozkulačování (od roku 1918), nebyli Korejci z Dálného východu nijak významně postiženi, protože měli většinou jen velmi malý majetek. Řízená a násilná kolektivizace začala probíhat v SSSR ve velké míře až po roce 1928. 
„Dědečkův bratr měl z fronty komunistickou průpravu a hned začal s rozkulačováním - nejbohatšímu Korejci ve vesnici vzal půdu a rozdával ji těm, kdo ji neměli. Ti byli nadšení, a také začali podporovat Rudé. Dědečkův bratr shromáždil „armádu“, $i$ když to byli spíše bandité. Po vítězství Rudých se dědečkưv bratr stal okresním tajemníkem. Když později přišly stalinské čistky (1936-1938), tak dědečkova bratra zastřelili bez soudu, jeho manželku uvěznili a o osudu jejich dcery nikdo neví. Dědeček pracoval ve škole a toho zastřelili taky. Během čistek přišlo o život kolem 4000 Korejců." (Vladislav Viktorovič Chan, Terénní výzkum, Taškent 2014)

„Během kolektivizace na Dálném východè se Korejci moc nebouřili, protože jsou zvyklí dodržovat zákony a príliš neprotestovat - to je ta konfuciánská tradice." (Vladimir Jefimovič San, Kazachstán, Terénní výzkum, Astana 2015)

V tomto období (do roku 1937) byli Korejci na ruském Dálném východě už z velké části integrováni do života v regionu Dálného východu - nejčastěji žili v kompaktních oblastech, kde tvořili většinu. Postupně docházelo k přejímání určitých kulturních prvků ruského okolí a zároveň docházelo i k politickému tlaku sovětského vedení.

Velice zřetelně to bylo možné pozorovat například na písních. Kromě původních korejských se stávaly ve 30 . letech 20 . století velmi populární sovětské budovatelské písně (Leninova píseň, Píseň traktoru). Tyto písně jsou dnes považovány sovětskými Korejci za součást jejich kultury, přestože pro mladou generaci znamenají podstatně méně. Na přelomu tisíciletí byl proveden dotazníkový průzkum, jakou jednotlivé generace sovětských Korejců preferují hudbu. Nejstarší generace sovětských Korejců preferuje korejskou tradiční hudbu (79 \%), zatímco druhá generace sovětských Korejců má širší preference od korejské tradiční hudby (32 \%) přes korejskou populární (28 \%) až k ruské populární hudbě (18 \%). Třetí generace preferuje ruskou populární (29 \%) a západní hudbu (21 \%). Nejmladší generace jednoznačně upřednostňuje západní hudbu (63 \%) (Hae-Kyung 2000: 125, 133-134).

\section{Deportace Korejců do Střední Asie}

K násilnému přesunu Korejců z ruského Dálného východu do Střední Asie došlo v roce 1937. Zde už žilo několik desítek Korejců, někteří ještě z carské doby. Ve 20. letech 20. století se jejich počet zvýšil v souvislosti s akcí, která měla vést k soběstačnosti SSSR v produkci rýže. Další Korejci se do Střední Asie dostali z Dálného východu během stalinských čistek ve 30. letech, kdy jim byl uložen trest vyhnanství. 
Deportace Korejců do Stř̌ední Asie podle nařízení Sovětu lidových komisařů №1428-326ss byla první v řadě stalinských přesunů obyvatelstva. Vysídlení bylo oficiálně odůvodněné obavou z jejich špionáže ve prospěch Japonska. Jak ale uvádí G. N. Kim (2014) na základě studia sovětských dokumentů, o deportaci Korejců uvažovalo vedení komunistické strany již v letech 1927, 1930 a 1932.

„Mluvit o přesunu se začalo už v srpnu 1937, v záŕí to bylo oficiální a hned druhý den, co to vyhlásili, se odjiždělo. Korejci ještě odevzdávali obilí, dostali potvrzení a slibovali jim, že za nimi pošlou i jejich zvírata, což nebyla pravda. Část Korejců si mohla podle nařizení pred odsunem do Střední Asie vybrat, zda nechtějí emigrovat do Koreje nebo do Japonska. Pokud nestihli odejit, nebo neměli pas, šli s odsunem. Podle toho, co se povídalo, tak každý, kdo odešel do Koreje, byl později v Severní Koreji zastřelen." (Vladislav Viktorovič Chan, Terénní výzkum, Taškent 2014)

Pokud vysadili odsunuté Korejce ve stepi, museli první zimu přečkat v zemljankách, chýše a domy si stavěli až mnohem později. Respondenti popisovali, že v zemljankách začaly brzo umírat hlavně děti na průjem, kašel, záněty. Korejci, které vysadili v okolí větších měst, měli velké problémy získat i málo placenou práci.

„Po dlouhé cestě z Dálného východu do Gurjeva nemohli mí př́buzní sehnat práci. Můj strýc nám ukazoval celý kufr státních vyznamenání a řádů, které dostal na Dálném východě, ale práci neměl celý podzim a zimu. Jednou, když přišel domů, na protest všechno i s kufrem spálil."(Vladimir Kim, *1933; Kim - Kim 2007: 63)

Hodnocení cesty do Střední Asie ze strany respondentů se výrazně liší. Protože někteří respondenti vnímají relativně bezproblémové soužití s obyvatelstvem Kazachstánu a Uzbekistánu, nepovažují ani samotný odsun za př́íliš drastický.

„Na Dálném východě museli Korejci všechno nechat, ale vlastně si polepšili, protože ve Střední Asii se jim pak vedlo mnohem líp. Začátky byly těžké, ale rychle jsme se vypracovali.“ (Respondentka, 63 let, Terénní výzkum, Taškent 2014)

Na druhou stranu ti, kteří odsun sami zažili, nebo jim o něm vyprávěli přímí účastníci, vnímají tuto akci jednoznačně negativně. 
„Rok 1937 a i pár let, které tomu předcházely, jsou pro Korejce úplně nejhorším obdobím. Odsun znám jenom z vyprávění rodičů, a to bylo něco strašného - lidi vezli v dobytčácích, spousty jich pomřelo cestou a spousty na místě. Trvalo 2 roky, než začali pořádně bydlet. Postupně osídlili celý surchandarjinský rajon u Taškentu.“ (Předseda spolku NOIN, Terénní výzkum, Taškent 2014)

Po odsunu z ruského Dálného východu zůstaly ještě menší skupiny Korejců v dalších částech Ruska - podle sčítání obyvatel v roce 1939 žilo v Rusku 13524 Korejců (nejvíce ve Volgogradské oblasti a Jakutské ASSR). Někteří z nich se po skončení 2. světové války přestěhovali do Střední Asie, kde již bylo kompaktní korejské osídlení a Korejci začínali být hospodářsky úspěšní.

„Nás do Uzbekistánu nedeportovali, my jsme se přestěhovali dobrovolně po válce - v Krasnojarském kraji a kolem Bajkalu žili Korejci dlouhou dobu. Přesto se nás dotkly stalinské represe - $v$ roce 1937 popravili otce i dědečka. Do Uzbekistánu nás pozval maminčin př́buzný Kim Pen Chva, který byl předsedou kolchozu Polární hvězda." (Elvira An, Uzbekistán, *1936; Uzbekistonning tanikhli 2012: 15-17)

Další Korejci měli příbuzné v Číně, kam migrovali z Koreje především během japonské vlády v letech 1910-1945.

„Já nepocházím z Dálného východu, ale z Číny, kde také žije hodně Korejců. $V$ 80. letech jsem tam jel navštívit př́buznou, kterou jsem nikdy predtím neviděl a sešel jsem se tam i s př́buzným ze Severní Koreje. Severokorejci byli i tenkrát velice opatrní - jak jsem začal mluvit o nedostatcích kolchozů, tak se se mnou ten Severokorejec nechtěl ani bavit." (Vladimir Jefimovič San, Kazachstán, Terénní výzkum, Astana 2015)

Vztahy příchozích Korejců s obyvatelstvem Střední Asie byly podle slov místních i podle slov Korejců vynikající. Na republikové úrovni (v Kazašské SSR a Uzbecké SSR) k přímé perzekuci Korejců nedocházelo, ale centrálně řízené stalinské represe $\mathrm{s}$ vrcholem $\mathrm{v}$ roce 1938 se jim nevyhnuly.

Až do Stalinovy smrti v roce 1953 byli příslušníci všech deportovaných národů považováni za státně nespolehlivé. Během 2 . světové války proto nebyli Korejci povoláváni do armády, ale museli sloužit v tzv. pracovní armádě (trudarmija) - spíše se jednalo o trestanecké tábory na nejrůznějších místech SSSR. 
„Na začátku války teta moc plakala: jejího muže povolali do pracovní armády, přestože byl jediným živitelem svých malých dětí i mě jako sirotka. Navíc s námi žil dědeček - invalida bez nohy. “(Vladimir Kim, *1933; Kim - Kim 2007: 69)

Protože se ale v době povolávání do armády někteří Korejci zdržovali na jiných místech (například z důvodu studia), bojovali někteří z nich i na frontě.

Už během 2. světové války se někteří Korejci stěhovali do sousedních svazových republik, kde očekávali lepší podmínky. Téměř vždy bylo toto stěhování na základě pozvání příbuzných. Stále pro ně ale platil přísný zákaz volného pohybu.

„Začátkem války odjižděly některé presídlenecké rodiny ke svým

př́buzným do Kazachstánu nebo Uzbekistánu. Vyprávěli,

že je tam chleba dosyta, a dokonce i rýžová kaše. Až když se ukázalo, že teta má nějaké př́buzné v Taškentské oblasti, tak jsme za nimi mohli na pozvání odjet. Bez toho dokumentu to nešlo."(Vladimir Kim, *1933; Kim - Kim 2007: 70)

I po skončení války existoval pro Korejce zákaz volného pohybu - i na cestu do sousedního okresu potřebovali povolení. Zrušení zákazu přišlo až s uvolněním poměrů, kdy byl 1. tajemníkem komunistické strany N. S. Chruščov. V tomto období byli Korejci pro svou pracovitost i oceňováni nejvyššími státními vyznamenáními.

„Korejci byli šikovní, ale dlouhou dobu nikdo z nich nebyl Hrdina socialistické práce. Teprve až k nám přišel milovník kukuřice Chruščov a viděl, že jedna Korejka má kukuřici vysokou přes 3 metry, tak se ptal, proč nedostává ocenění. Hned to ocenění dostala a pak už Korejci ocenění soc-truda začali dostávat.“ (Předseda Spolku NOIN, Terénní výzkum, Taškent 2014)

První korejské kolchozy vznikaly ještě na Dálném východě a po příchodu do Střední Asie začali Korejci na nových místech zakládat kolchozy nové. Zanedlouho si jich začali místní obyvatelé vážit pro jejich mimořádnou pracovitost. Tu dokazovali i tím, že z bažin a rákosí dokázali udělat úrodná pole.

Poválečné období se stalo pro středoasijské Korejce přelomovým z hlediska jejich zapojení do většinové společnosti. Původní zcela korejské kolchozy byly malé a až při jejich spojování na přelomu 50. a 60. let 20. století se začala zvyšovat jejich produktivita. Spojování kolchozů ovšem vedlo k tomu, že dříve národnostně jednotné kolchozy se proměnily v národnostně smíšené. 
Jako příklad může posloužit jeden z nejúspěšnějších kolchozů v Uzbekistánu Polární hvězda. Na místo dnešního kolchozu (vesnice) přišli Korejci v roce 1937, kolchoz vybudovali později. V rámci stalinských represí byli první dva předsedové kolchozu zatčeni ještě na Dálném východě, třetího předsedu, který byl deportován s ostatními Korejci, zatkli v Uzbekistánu. Spojením kolchozů v 60. letech vznikla hospodářská jednotka s výměrou 3127 ha (a původním názvem Polární hvězda), kde žilo 1924 rodin (7 828 osob). Ve sloučeném kolchozu už byli početně na prvním místě Uzbeci (33 \%), dále zde žili Kazaši (26 \%) a Korejci tvořili jen 20 \%. Mezi další obyvatele kolchozu patřili Ujguři, Rusové, Tataři, Turci.

Sovětské kolchozy se vyznačovaly výraznou závislostí jednotlivých členů na kolchozním hospodaření - kolchoz byla instituce, která všestranně zabezpečovala život obyvatel. Kolchoz zajištoval kromě pracovních míst rovněž obchody, jesle, školky, školy, nemocnice, kulturní vyžití.

„V našem kolchoze jsme měli všechno - nemocnici, školu, dokonce jsme měli do každého domu zavedený rozhlas, aby mohl předseda všechny svolávat. $V 6$ ráno byl pro všechny budíček a u předsedy Kima začínala schůze vedoucích oddělení. Pak se šlo na snídani a do práce. Dělalo se do večera a $\vee 9$ nebo $v 10$ večer byla u predsedy schůze."(Př̀edseda Spolku NOIN, Terénní výzkum, Taškent 2014)

Kolchozní vedení odměňovalo nejpracovitější členy tím, že jim pronajímalo kolchozní půdu.

„Později Korejci hrozně zbohatli, když si někteř́ brali do pronájmu kolchozní půdu. Museli splnit předepsaný plán a toto stanovené množství prodat státu za výkupní ceny. Ty byly směšně nízké na bazarech stály věci 10-15 x víc. To, co ale Korejci vypěstovali nad plán, si mohli nechat a sami prodat na bazarech. Pro korejskou kulturu to bylo moc špatné, protože sice půl roku dřeli, ale v zimě to propili a prohráli v kartách - hraní karet bylo pro Korejce typické. Přestože byl alkoholismus u mnoha Korejců velkým problémem, stejně ušetřili hodně peněz na vzdělání dětem. “ (Korejský respondent, 55 let, Terénní výzkum, Taškent 2014)

Jiný korejský kolchoz, Politotděl, se stal v 60. letech nejlepším v celém Uzbekistánu.

„V Politotdělu chtěli všichni bydlet, protože to tam bylo po všech stránkách nejlepší, všichni měli auto. Získat tam povolení k pobytu bylo dražší, než do Moskvy. Koupit tam dům bylo úplně nemožné, domy se jenom dědily. Kolchoz měl 


\section{i fotbalový klub, který hrál celosvazovou ligu. “(Korejská} respondentka, 63 let, Terénní výzkum, Taškent 2013)

Pracovitost Korejců (a bezproblémové vztahy s nimi) podle slov místních Uzbeků stála v protikladu ke vztahu k jiným národnostem na území Uzbekistánu. Bohatství, kterého Korejci dosáhli, vyplývalo z tvrdé práce, čehož si byli všichni vědomi. Pouze na místní úrovni byly občas nějaké drobnější výpady - korejským dětem se uzbecké děti např́iklad posmívaly, že jsou šikmoocí a že jedí psy.

Jiná situace byla u těch přesídlených národů, pro které byl typický obchod. Podstatně horší vztahy tedy měli místní obyvatelé například s Meschetskými Turky nebo s židovským obyvatelstvem, jejichž bohatství vyplývalo převážně z obchodování.

\section{Školství}

Důraz na vzdělávání má v korejské kultuře dlouhou tradici. Již ve středověku získávali lidé v Koreji, kteří složili zkoušky na pozici státního úředníka, celoživotní zabezpečení. Vzdělání sice bylo po staletí výsadou pouze vládnoucí vrstvy, ale tato úzká skupina yangban se právě prostřednictvím nutnosti skládat zkoušky stále měnila - na privilegia vždy nebyl dědičný nárok (Han 2010: 66).

Protože vzdělání dětí bylo (a je) pro Korejce velmi důležité, posílali v sovětském období rodiče děti na studia do měst, nebo sami i s dětmi do měst odcházeli.
„Korejci jsou hodně pracovití - prestože se u nich dost vyskytuje
alkoholismus nebo hazard, nikdy neuvidíte v Uzbekistánu
Korejce, který by žebral. Práci v kolchozu jsem zažil
na vlastní kůži, a to byla strašná dřina - když se pěstovala rýže, tak se muselo stát od rána do večera po kolena ve vodě, mechanizace žádná, a nohy zničené, odlupovaly se nám celé pláty kůže. Proto jsem také rád odešel do města." (Viktor Nikolajevič Pak, *1958, Terénní výzkum, Taškent 2014)

S odchodem do měst se radikálně změnilo používání jazyka. Korejci mluvili doma korejsky, ale po přestěhování do měst začali rodiče na své děti mluvit rusky, aby se líp naučily ruštinu, protože korejština byla ve městech nepoužitelná.

Část Korejců ovšem žila ve městech hned po deportaci z Dálného východu. V uzbeckém Taškentu měli Korejci i vlastní bazary a dříve zde byly celé korejské čtvrti (například Fitratova ulice, Mirabád). I v těchto kompaktních korejských jednotkách ale docházelo k poměrně rychlým kulturním proměnám 
a i zde se korejský jazyk stával stále méně potřebným. V době urbanizace života středoasijských Korejců docházelo i k demografickým změnám. Zatímco dříve byly u Korejců běžné rodiny s 6-8 dětmi, ve městech došlo k poklesu na 2 děti. Z původně vesnického obyvatelstva se Korejci stávali typicky městským obyvatelstvem. Podle sčítání obyvatel v Kazachstánu z roku 2009 byli Korejci ze všech národů Kazachstánu na prvním místě v podílu městského obyvatelstva: 83,8 \%. Korejci byli mezi všemi národy Kazachstánu rovněž na prvním místě v podílu obyvatel s vyšším vzděláním, kterého dosáhlo 47,1%osob (Smailova 2011: 22, 45).

\section{Hlavní prvky etnické identity středoasijských Korejců}

V literatuře zabývající se proměnou identity přistěhovalců se setkáváme s pojmem „efekt třetí generace“, který lze zjednodušeně popsat takto: syn chce zapomenout na to, na co se vnuk snaží vzpomenout, protože jako příslušník třetí generace silně pocituje vykořeněnost. První generace mívá obvykle problémy orientovat se v nové společnosti, sílu čerpá ze vzpomínek a tradic, druhá generace již přejímá hodnoty a stereotypy nové společnosti a zároveň může docházet ke konfliktům s první generací. Třetí generace se často vlastní identitu pokouší uměle konstruovat (Baštecká 2013: 231).

V př́ípadě sovětských Korejců je situace podstatně složitější, protože procesem asimilace a hledáním místa v nové společnosti procházeli vícekrát. Nemáme zde tedy tři ukázkové generace, ale hledajících generací je více, protože k adaptaci docházelo nejen při stěhování, ale i se změnou politického systému po rozpadu SSSR.

\section{Podle generací můžeme tedy Korejce rozdělit do těchto skupin:}

1. Narození v Koreji, žili v Koreji - o těchto příbuzných sovětští Korejci většinou nic nevědí, ani jak se jmenovali.

2. Narození v Koreji, přestěhovali se do Ruska - část těchto Korejců se snažila o všestrannou asimilaci (přijímáním pravoslaví, změnou korejských jmen na ruská).

3. Narození v Rusku, žili v Rusku - přes snahu svých rodičů o asimilaci měli ve své kultuře stále mnoho korejských kulturních prvků, což bylo dáno i vzděláváním v korejštině.

4. Narození v Rusku, deportovaní do Střední Asie - deportací Korejců došlo $\mathrm{k}$ jejich druhému vykořenění a postupnému přijímání sovětské kultury.

5. Narození ve Střední Asii, většinu života prožili v sovětském období žádný z nich již nemá korejské jméno, korejská zůstala pouze příjmení. Část těchto Korejců se snaží o udržení rychle mizejících korejských tradic nebo specifického jazyka sovětských Korejců, další část už o korejské tradice zájem nemá. 
6. Narození ve Střední Asii, většinu života prožili po rozpadu SSSR nejmladší generace sovětských Korejců je zřejmě kulturně nejvzdálenější kultuře Korejců Severní i Jižní Koreje.

Vazby sovětských Korejců na Koreu (at' Severní, nebo Jižní) jako na zemi otců nebyly v dobách SSSR nijak silné, protože na Dálném východě se už narodily zhruba tři generace ruských/sovětských Korejců. Navíc v Koreji neexistovalo příliš mnoho věcí, ke kterým by sovětští Korejci mohli vzhlížet Severní Korea rozhodně nebyla příkladem hospodářského úspěchu a i jižní Korea patřila dlouho mezi značně zaostalé země. Přes dávnou kulturní tradici žilo po skončení 2 . světové války v Koreji 78 \% negramotných dospělých obyvatel (Savada - Shaw 1997: 115).

V tomto ohledu měl zpočátku SSSR se svou životní úrovní určitý náskok. V době, kdy už patřila Jižní Korea mezi vysoce rozvinuté státy, fungovalo navíc ideologické informační embargo.

„My jsme si pořád mysleli, jak se v Jižní Koreji žije špatně. Pak přišla olympiáda $v$ Soulu $v$ roce 1988 a nikdo se nestačil divit, jak to tam nádherně vypadá. Do té doby jsme neměli národní sebevědomí nijak vysoké, ale pak se určitě zvedlo, když jsme viděli tu ekonomickou úspěšnost Koreje. Po rozpadu SSSR podporovala jihokorejská vláda repatriaci, nebo alespoň udělovala uzbeckým Korejcưm třileté pracovní vízum.“(Respondent, 65 let, Terénní výzkum, Taškent 2014)

Ne všichni sovětští Korejci ale považovali za zemi zaslíbenou právě Jižní Koreu. Někteří využili jen možnost získat pracovní vízum a pak se vraceli do Střední Asie. Svoji roli určitě sehrálo i to, že Jihokorejci občas dávali sovětským Korejcům najevo vlastní nadřazenost.

Někteří Korejci se začali vracet ze Střední Asie domů na Dálný východ. Jednalo se ve větší míře o Korejce z Uzbekistánu než Kazachstánu, protože se uzbečtí Korejci mohli (oproti kazašským Korejcům) cítit v nově samostatné republice více jako cizorodý prvek - především kvůli svému zevnějšku. Tato odlišnost v Kazachstánu neexistovala.

„Hodně Korejců odsud odjelo domů na Dálný východ. Za Sovětského svazu to bylo v některých ohledech lepši - nikdo se moc nedíval na národnost a všichni spolu mohli mluvit rusky. Jak se stal Uzbekistán samostatný, tak měli najednou Uzbeci všude výhody. My mluvíme rusky, a když uzbecky někdo z Korejců trochu umí, tak se často stydí tu řeč používat. Máme asijský obličej, tak se neschováme. Na Dálném východě s tím problém není.“ (Respondent, 70 let, Terénní výzkum, Samarkand 2014) 
Určit nejvýznamnější odlišnosti mezi středoasijskými Korejci, Severokorejci a Jihokorejci je velmi obtížné, protože různí respondenti považují za hlavní součást své kultury někdy velmi odlišné prvky. U středoasijských Korejců navíc dochází v jejich kultuře (kultura ve smyslu způsob života) vlivem asimilace k překrývání kultury korejské, ruské (sovětské), uzbecké, kazašské.

\section{Jazyk}

Používání vlastního jazyka je velmi často jedním z pilírư etnické identity. I v případě jazyka se můžeme setkat se dvěma krajnostmi chápání jeho významu - esencialistické (např́íklad Herder (1772) chápe jazyk jako srdce národa) a konstruktivistické (jazyk a odvozená etnická identita nejsou stálé a jsou věcí dohody) (Lytra 2016: 133). Jazyk může velmi dobře posloužit jako vstupenka (nebo závora) mezi členy určité skupiny - řeč se specifickým přízvukem ihned odhaluje „ty ostatní“ a vymezuje je vůči „nám“. Jazyk ovšem mívá i další funkci - může se jednat o jakýsi poklad nebo památku na předky. I když neslouží ke každodennímu používání, je mezi členy skupiny silné povědomí o společném jazyku jako jednoho $\mathrm{z}$ atributů společného původu. To je právě případ sovětských Korejců, kteří většinou korejštinu neovládají, ale její význam stále oceňují.

Na používání korejštiny měla největší vliv možnost učit se tento jazyk i ve škole. V carské době byly na Dálném východě hlavně církevní školy, ale učilo se v nich i korejsky. Vzdělanci uměli rusky, korejsky, japonsky a čínsky. I po převzetí moci bolševiky se ve školách korejsky vyučovalo. Ve 20.-30. letech 20. století fungovalo na Dálném východě více než 300 korejských škol, dvě střední korejské pedagogické školy, v roce 1931 byl ve Vladivostoku založen korejský pedagogický institut - první korejská vysoká škola v Rusku. Korejská oddělení byla i na Dálnovýchodní univerzitě a na Vyšší komunistické zemědělské škole. V korejštině vycházelo 6 časopisů a 7 novin (Chegaj 2015).

Výuka v korejštině skončila ve Střední Asii v roce 1939 a k jejímu částečnému obnovení došlo až po válce. To už se ale vyučovalo rusky - korejštinu měly děti jako cizí jazyk až do 70. let, kdy se s výukou korejštiny přestalo úplně.

„Já umím trochu korejsky, ale to je jenom moje generace (kolem 70 let). Když jsem chodil do školy, bylo všechno v ruštině a jako druhý jazyk jsme ani korejštinu neměli. Učila se němčina (2 hodiny týdně), protože tam, kde jsme žili, bylo i hodně Němců." (Vladimir Jefimovič San, Kazachstán, Terénní výzkum, Astana 2015)

Je třeba si uvědomit, že i v případě jazyka došlo mezi Korejci žijícími na Dálném východě (a později ve Střední Asii), v Severní a Jižní Koreji k výrazným odlišnostem. Přestože se ve všech těchto případech používá k označení jazyka pojem „korejština“, vzájemné rozdíly jsou často za hranicí 
srozumitelnosti. Korejci, kteří přišli do Ruska z oblasti dnešní Severní Koreje, používali dialekt, který se značně odlišoval od dialektu z Pchjongjangu a ještě větší odlišnosti vykazoval oproti dialektu v Soulu, který se stal základem standardní korejštiny v Korejské republice. Rozdíly jsou v hláskovém systému, pravidelnosti a nepravidelnosti sloves, jiného způsobu tvorby množného čísla, počtu zdvořilostních stupňů (Stöckelová 2013: 46-68).

„Já korejsky umím, korejštinu jsem i vyučovala, byla jsem na návštěvě i v Jižní Koreji. Když ale mluvím naší korejštinou, tak je to pro Jihokorejce někdy jako cizí řeč. Sovětská korejština je mnohem víc podobná severokorejštině a také se do ní dostalo spousty slov z ruštiny nebo uzbečtiny. Pro některá slova máme vlastní označení - jako třeba vědru, které Korejci vůbec neznali, ř́káme medre nebo zápalkám ř́káme v naší korejštině pidžiki.“ (Respondentka, 73 let, Terénní výzkum, Taškentská oblast 2014)

V současnosti probíhají v Taškentu jazykové kurzy korejštiny podporované korejskou vládou, ale navštěvují je i Uzbeci, kteří chtějí pracovat v Jižní Koreji. Počet Uzbeků na jazykových kurzech už převyšuje počet uzbeckých Korejců. Výuka korejštiny pro sovětské Korejce už ale většinou neslouží k obnovení rodného jazyka, ale spíše se jedná o učení cizího jazyka.

Přestože specifický jazyk sovětských Korejců rychle mizí, podle posledního sčítání obyvatel v Kazachstánu v roce 2009 označilo korejštinu jako rodný jazyk 36 \% místních Korejců (Smailova 2011: 22), v Rusku podle sčítání z roku 2010 pak pouze 28 \% Korejců uvedlo, že ovládají korejštinu. Naopak celých 96 \% ruských Korejců ovládá ruštinu (v Uzbekistánu aktuální údaje chybí).

\section{Stravování}

Jídlo je velice silným nástrojem, kterým lze projevovat vlastní identitu a zároveň vyjadřuje mnoho symbolů - náboženských, etnických, společenských. Mnoho kultur se prostřednictvím jídla vymezuje vůči kulturám jiným a prríkladem výrazného vymezení je i kuchyně sovětských Korejců. Přes výraznost vymezení není tato odlišnost (až na výjimky) vnímána okolím negativně.

Korejské národní jídlo kimči, připravované fermentací a kořeněním především zelí, podávané spíše jako příloha, je typické pro obyvatele Korejského poloostrova i pro sovětské Korejce. Jíst kimči ukazuje korejskou identitu a vymezuje Korejce - nejen sovětské, ale i Korejce na dalších místech světa (Young 2015).

Kuchyně Korejců ve Střední Asii a Rusku je typická především modifikací původních korejských jídel, která se připravují z jiných surovin. Některá místní (ruská) jídla naopak korejské přísady získala - do ruského boršče 
občas přidávají sovětští Korejci rýži. Naopak v mnoha restauracích sovětských Korejců se místo rýže podává ruská př́íloha - bílý chléb (Song 2016).

Protože v sovětském období bylo obtížné sehnat pekingské zelí, nahrazovalo se mrkví. Postupně se staly mrkvové saláty pro sovětské Korejce typické a velice oblíbené i pro místní obyvatele, kteří je doposud ve velkém množství kupují na městských bazarech celého postsovětského prostoru. Někteří sovětští Korejci, kteří navštívili Koreu, byli překvapení, že korejská mrkev je v Koreji naprosto neznámou věcí.

S Korejci je ze strany vnějších pozorovatelů spojeno pojídání psího masa. Přestože se v Koreji nejedná o časté jídlo, právě tato (spíše velmi sváteční) součást korejského jídelníčku je pro vnější pozorovatele nejvíce šokující. Oblibu psího masa u sovětských Korejců nedokázaly odstranit ani zákazy nebo dokonce postihy. Respondenti v Uzbekistánu vyprávěli, že v sovětském období nemohli ve vesnici připravovat jídla ze psího masa, ale měli k tomu účelu zařízený přístř̌ešek za vesnicí. V současnosti mají středoasijští Korejci své restaurace, které připravují jídla ze psího masa, a tyto restaurace ve stále větší míře navštěvují i Kazaši nebo Uzbeci. Obliba psího masa vedla i k občasnému posměšnému označování Korejců ze strany jejich sousedů jako sabakojedy (jedlíci psů).

V Taškentu, kde vedle sovětských Korejců žije početná jihokorejská komunita, jsou korejské restaurace striktně oddělené (a odlišně preferované) podle toho, zda jsou „sovětské“, nebo „jihokorejské“. To však nebrání příslušníkům dalších národností, aby tyto restaurace navštěvovali také (což dříve obvyklé nebylo).

Přes výrazné ovlivnění korejské kuchyně okolím zůstává specifická příprava stravy a volba korejských jídel zřejmě nejvýraznějším odlišujícím znakem sovětských Korejců.

\section{Svátky}

Některé prvky původní korejské kultury se k sovětským Korejcům mohou dostávat nepřímo - ačkoli mnohé zvyky sovětští Korejci dodržovali málo nebo vůbec (oslava 100 dnů od narození dítěte, oslava 60. narozenin chvegab), stává se, že při hledání vlastní identity dochází k objevování a dodržování starých korejských zvyků. To potvrzuje i autor knihy Zvyky a obyčeje Korejců $v S N S$, podle kterého někteří Korejci začali slavit nějaké svátky až na základě četby jeho knihy (Li 2001).

Přesto sovětští Korejci nejvíce slaví svátky, mající původ v sovětských dobách (8. 3. Mezinárodní den žen, 9. 5. Den vítězství a 31. 12. oslava konce kalendářního roku).

Příkladem dalších odlišností mezi korejskými skupinami je počítání věku - zatímco sovětští Korejci počítají svůj věk podle data narození, ostatní Korejci k věku ještě připočítávají 9 měsíců. Tento způsob určování věku byl ještě 
rozšířený u ruských Korejců, kteří se narodili před 2. světovou válkou - ti navíc ještě používali lunární kalendář.

„Já jsem ročník 1952 a věk jsem vždycky počítal normálně podle data narození, a ne jako Jihokorejci, kteři prípočítávají

9 měsícủ. Moje matka takhle ještě počítala své narozeniny.“

(Respondent z Taškentu, Terénní výzkum, Taškent 2014)

\section{Náboženství}

V Koreji měl dlouhou dobu velmi silnou pozici konfucianismus (s vlivy buddhismu a taoismu) ve své formě označované jako neokonfuciánství (Jujahak). Jujahak představoval komplexní systém ovlivňující každodenní život člověka od dospívání, svatby, pohřbů a obřadů týkajících se úcty k předkům. Jujahak rovněž striktně určoval vztahy mezi jednotlivými vrstvami společnosti. Přestože již od 17. století nebyl tento systém zcela soudržný, korejská vláda drasticky trestala odchylky od systému - například křestanské misionáře a místní konvertity (Inside the Catholic Church... 2010: 12-13). Náboženství v Koreji (kromě oficiálního, spíše filozoficko-politického systému Jujahak) ovšem bylo dlouho nejednotné a vykazovalo mnoho synkretických prvků z buddhismu, taoismu nebo šamanismu (Hanuš 2016). V 19. století se v souvislosti s korejským národním hnutím začalo formovat nové náboženství Čondogyo, které se mělo stát součástí budovaného korejského národa (s jednotným územím na Korejském poloostrově, jazykem, kulturou i náboženstvím). Čondogyo se stalo politickým nástrojem korejských nacionalistů na začátku 20. století v boji za samostatnost proti Japonsku.

Korejci, kteří odcházeli od 19. století do Ruska, většinou neměli problém $\mathrm{s}$ přestupem k pravoslaví. Protože z té doby neexistují výzkumy, které by sledovaly i neformální religiozitu korejského obyvatelstva v Rusku, můžeme se jen domnívat, nakolik za konverzemi stála přitažlivost pravoslavné víry a nakolik se jednalo pouze o vnější projev loajality vůči ruskému státu.

„Korejci na Dálném východě byli hlavně pravoslavní. Když jsem se ptala mé matky, jaké měla původní korejské jméno, tak si na ně už ani nepamatovala, znala jenom ruské. “(Průvodkyně, Uzbekistán, 73 let, Terénní výzkum, Taškentská oblast 2014)

Pravoslavné náboženství se ovšem u ruských Korejců nestačilo stát plnou součástí jejich nové identity. Po bolševické revoluci v Rusku byli věřící (včetně pravoslavných Korejců) perzekuováni a k dalšímu výraznému odklonu od pravoslaví došlo po jejich vysídlení do Střední Asie. V nových místech došlo i v případě Korejců k výraznému vytváření nového (sovětského) člověka, kterému měly být bližší komunistické ideály než jakékoli náboženství. Teprve 
po rozpadu SSSR docházelo (nejen u korejských obyvatel) k hledání nových kořenů, přičemž významnou roli hrálo náboženství. Zatímco u středoasijských národů (Uzbeci, Kazaši, Kyrgyzové) došlo k renesanci islámu, u Korejců bylo toto hledání výrazně složitější - někteří se vraceli k pravoslaví, jiní k buddhismu a některé oslovili nově příchozí křestanští misionáři. U části Korejců je doposud patrné hledání náboženského ukotvení.

„V dobách SSSR všichni věřili Stalinovi a Leninovi. To bylo naše náboženství, naše víra. $V$ 90. letech přišli do vesnice baptističtí misionárí, líbilo se mi, co ř́kali, takjsem se k nim dala, protože každý musí něčemu věřit." (Respondentka, 74 let, Terénní výzkum, Taškentská oblast 2014)

„Protestantští misionáři k nám do Uzbekistánu chodili z Jižní Koreje, hlavně v letech 1993-1995. Ted'odhaduji, že je ve městě kolem 150 korejských protestantů." (Správce protestantského kostela, Terénní výzkum, Samarkand 2014)

\section{„Do katolického kostela $v$ Taškentu, který byl původně hlavně pro domácí Poláky, chodí jak místní Korejci, tak i Jihokorejci - každý týden máme pravidelné mše v korejštině." (Katolický kněz, Terénní výzkum, Taškent 2013)}

V roce 2009 se v Kazachstánu poprvé od roku 1937 při sčítání obyvatel zjištovala náboženská příslušnost $\mathrm{u}$ jednotlivých etnik, ale v konečných výsledcích se nezohledňuje rozdělení hlavních náboženských skupin. Podle tohoto sčítání je mezi Korejci nejvíce rozšířené křestanství (49 \%), 29 \% Korejců se označilo za nevěřící a 11 \% za buddhisty (Smailova 2011: 25).

\section{Závěr}

Protože předkové sovětských Korejců odešli z Koreje před 150 lety, došlo k významné proměně jejich způsobu života ve srovnání s Korejci na Korejském poloostrově. Přestože Korejci žijí ve Střední Asii od 30. let 20. století, přijetím sovětské kultury se stali podstatně více „evropští“ (podobně jako ostatní středoasijské národy bývalého SSSR). Sovětští Korejci nemohli dlouhou dobu navazovat kontakty s Koreou (at' Severní nebo Jižní) - to bylo možné, až to dovolovaly politické podmínky. Při návštěvách Koreje (v sovětském období téměř výhradně Severní, po rozpadu SSSR naopak téměř výhradně Jižní) pak stále více poznávali zásadní kulturní odlišnosti. Jejich etnická identita se pak odvíjela podle toho, o jakou generaci Korejců se jednalo.

Nelze tedy hovořit o jednotné korejské kultuře, protože způsob života všech zmiňovaných korejských skupin je diametrálně odlišný. Sovětští Korejci 
ve Střední Asii považují za hlavní prvky, kterými se odlišují od většinové společnosti, především ruský jazyk, který mají ve většině případů jako rodný - korejština je pro většinu $\mathrm{z}$ nich pouze součást historického povědomí. Ve všech dalších ohledech, kromě způsobu stravování a odlišného historického povědomí, se velmi podobají většinové společnosti nebo ruské etnické skupině.

Mezi důležité vlivy působící na asimilaci Korejců na území bývalého SSSR je bezesporu i jejich fyzická odlišnost (nebo podobnost). Korejci v Kazachstánu se snadněji a výrazněji asimilovali i proto, že jsou Kazachům vzhledově podobní. V Uzbekistánu Korejci mnohem více „vyčnívají“, a proto jejich asimilace není tak výrazná.

Vliv státu na etnickou identitu různých skupin Korejců můžeme ukázat na všech korejských skupinách v případě jazyka. V Severní a Jižní Koreji došlo po rozdělení země a odlišné zahraniční orientaci k proměně jihokorejštiny, která přijala velké množství slov z angličtiny. Vzdalování obou zemí je patrné na míre dodržování tradic i na míre religiozity. Kultura sovětských Korejců vstřebala celou řadu prvků, kterými se tito Korejci zásadně odlišují od Korejců v Koreji. Stát tedy působí nejen jako „dodavatel“ vlastní kultury, ale zároveň se jeho vliv projevuje na oddalování nebo přibližování kultuře původní země, v tomto případě tedy Koreje.

Oddělení od národního státu má na etnickou identitu velký vliv. Sovětští Korejci narození ve Střední Asii považují za domov již republiku, ve které žijí, případně za domov (zemi otců) považují ruský Dálný východ. Korea je pro ně země sice mimořádně blízká, ale svou budoucnost s ní nespojují nijak pevně. Část těchto Korejců ovšem silně vnímá etnické vykořenění - považují se za cizince v Koreji i v republice, kde se narodili.

\section{Červenec 2017}

\section{Literatura}

Baštecká, Bohumila. 2013. Psychosociální krizová spolupráce. Praha: Grada. Ditrych, Ondřej. 2004. Vymysliti si středoasijské národy... Navýchod 3: 11-12. Eriksen, Thomas Hylland. 2007. Antropologie multikulturních společností. Praha: Triton. Grigorcevič, Stanislav Seliverstovič. 1958. Učastije korejcev russkogo Dal'něgo Vostoka v antijaponskoj nacional'no-osvoboditěl'noj bor'be. Voprosy istorii 10: 139-151.

Hae-Kyung, Um. 2000. Listening Patterns and Identity of the Korean Diaspora in the Former USSR. British Journal of Ethnomusicology 9 (2): 121-142.

Han, Young Woo. 2010. A review of Korean history. Gyeonggi-do: Kyongsaewon. Hanuš, Pavel. 2016. Jihokorejská kulturní specifika. Kulturní studia 2: 109-131. Herder, Johann Gottfried. 1772. Abhandlung über den Ursprung der Sprache. Berlin. Chan, Valerij Sergejevič - Sim, Chon Jong. 2014. Korejcy Central'noj Azii. Moskva: MBA. Chegaj, I. A. 2015. Korejcy Rossii: istorija i sovremennost'. (online) Mežregional'nye Issledovanija. [2015-09-16] Dostupné z: http:// mion.isu.ru/filearchive/mion_publcations/sib_kor/6.htm. 
Inside the Catholic Church of Korea. 2010. Seoul, Korea: The Research Foundation of Korean Church History.

Kim, German Nikolajevič. 2014. Děportacija. (online). Zagranica. [2015-09-07].

Dostupné z: http://world.lib.ru/k/kim_o_i/d2rtf.shtml.

Kim, Maxim Pavlovič. 1972. Sovetskij narod. Moskva: Politizdat.

Kim, Vladimir -Kim, Elvira. 2007. Ešelon - 58... ušel navsegda. Taškent: Turon-Iqbol.

Kokaisl, Petr - Usmanov, Amirbek. 2012. Dějiny Kyrgyzstánu očima pamětníků. Praha: Nostalgie.

Kokaislová, Pavla. 2013. Etnicita, nacionalismus a etnické menšiny. (online) Hospodářská a kulturní studia [2017-02-21] Dostupné z: http://www.hks.re/wiki/0:etnicita.

Korejcy. 2014. Almaty: Doknip.

Li, Grigorij Nikolajevič. 2001. Obyčai i obrjady korejcev SNG. Moskva, Taškent.

Lytra, Vally. 2016. Language and ethnic identity. In: The Routledge Handbook of Language and Identity. Routledge.

Muszynski, Alicja. 1994. Deconstructing the categorical reality. Canadian Ethnic Studies 26.3: 4.

Nasekin, Nikolaj. 1904. Korejcy Priamurskago kraja. Žurnal ministerstva narodnago prosveščenija 3/1904: 1-61.

Převalskij, Nikolaj. 1870. Putěšestvije v Ussurijskom kraje 1868-1869 g. S-Peterburg.

Roy, Olivier. 2007. The New Central Asia. New York University Press.

Savada, Andrea - Shaw, William. 1997. South Korea: A Country Study. Collingdale: Diane.

Simmel, Georg. 1890. Über sociale Differenzierung. In: Staats- und socialwissenschaftliche Forschungen herausgegeben von Gustav Schmoller. Leipzig: Duncker, Humblot.

Smailova, A. A. 2011. Itogi Nacional'noj perepisi naselenija Respubliki Kazachstan 2009 g. Astana: Agentstvo Resp. Kazachstan po statistike.

Solženicyn, Alexandr. 1999. Rusko v troskách. Praha: Práh.

Song, Changzoo. 2016. Kimchi, seaweed, and seasoned carrot in the Soviet culinary culture. Journal of Ethnic Food 3 (1): 78-84. doi:http://dx.doi.org/10.1016/j.jef.2016.01.007

Stöckelová, Linda. 2013. Korjŏmal - dialekt korejské menšiny v Kazachstánu. Praha: FF UK.

Šatava, Leoš. 2015. Evropská etnika bez státu. Trnava: FF UCM.

Tătar, Marius. 2010. Integration, Identity and Participation in a Changing Europe. Journal of Social Research \& Policy 2: 47-62.

Uzbekistonning tanikhli korejslari hakhida khiskhača makholalar. 2012. Taškent: Činor ENK. Young, Rae Oum. 2015. Authenticity and representation: cuisines and identities in KoreanAmerican diaspora. Postcolonial Studies 8 (1): 109-125.

doi:http://dx.doi.org/10.1080/13688790500134380 